\title{
THE EFFECTIVENESS OF PUBLIC VS PRIVATE SCHOOLS IN INDONESIA
}

\author{
Nenny Hendajany \\ Doctoral Program, Faculty of Economics and Business, Gadjah Mada University
}

\begin{abstract}
This paper examines the effectiveness of public versus private schools using the national exit exam of Junior Secondary Schools in Indonesia. Using Indonesian Family Live Survey (IFLS) (1997), IFLS (2000) and IFLS (2007), this study find evidence that graduates of the public school have higher scores on the national exit exam than those of the private school controlling a wide variety of students' characteristics and family background. This finding is robust to several estimates, including Ordinary Least Square (OLS), Fixed Effects (FE), and Instrumental Variable (IV). Using the score of the national exit exam (Ebtanas) as a standard score, public school students are higher 0.30, 0.247 and 0.572 of standard deviations for OLS, FE and IV estimates respectively.
\end{abstract}

Keywords: Education, Effectiveness, Public and Private Schools, IFLS

JEL Classifications: I24, I25

\section{INTRODUCTION}

The provision of social services is basically one of the government's responsibilities. Education is one of the social services provided by the government, as other social services like health. However, with a relatively limited funding, the government generally provides the service to the society in a minimum standard. The different background in social-economy, education, and way of thinking therefore makes some people need extra or better educational services than those provided by the government. This is what underlies the emergence of non-governmental social services or better known as private institutions which are commonly in Indonesia organized as foundations.

Based on this background, private institutions are supposed to be able to provide better service and better quality than the one provided by government. However, a lot of empirical studies demonstrated that public institutions (schools) are superior compared to the private ones. One of the benefits of public schools in Indonesia is the opportunity to get a better input (Newhouse and Beegle, 2006). While the ratio between 
teachers and students from private schools usually smaller than that of private ones, the empirical study from Newhouse and Beegle (2006) showed that the students' final test scores of public schools are relatively higher than those of the private schools with a deviation standard between 0.17 and 0.3 . This is one of the evidence that support the society's confidence on the perception that public school quality in Indonesia is better than that of the private school.

Several previous studies regarding the different type of schools in a number of countries show a variety of results. Evans and Schwab (1995), Sander (1996), Figlio and Stone (1997), and Neal (1997) for example, compared the effect of school type to such outcomes as achievement standard of cognitive test, opportunity to finish higher education, and opportunity to continue to higher education. Studies by Evans and Schwab (1995) and Neal (1997) showed that students of private school (Catholic) were more likely to finish their high school compared to students of public school. Nevertheless, Sander (1996), by using examination scores as a measurement, did not get a significant evidence of the effect of Catholic school on public school. Moreover, Figlio and Stone (1997) who compare the test scores between public school students, common private, and catholic private found a significant influence from common private and catholic private, but there was no important difference between public school students and catholic school students.

While in Columbia and Tanzania, Cox and Jimenez (1991) made the point that private school students had better test results compared to those of public school, in Indonesia, Newhouse and Beegle (2006) believed that public school students had higher test scores achievement than private school's ones. However, Bedi and Garg (2000), using data from Indonesian Family Life Survey (IFLS) 1993, discovered that graduates of private junior high schools are better off in the labor market than those of public schools.

These distinctive empirical results provide motivation of this research. In general, this study is intended to see the effectiveness of Junior High School's types measured by the scores on national exit exam when they are about to finish their Junior High School study. In other words, this study is aimed at finding out whether school type (public or private) contributes to the different academic achievement Junior High School completion. Specifically, this study refers to and replicates the paper entitled "The Effect 
of School Type on Academic Achievement: Evidence from Indonesia" written by Newhouse and Beegle in 2006 by making use of IFLS data in the year of 1993, 1997, and 2000. What makes this study different, however, is that this study employs pooling crosssection from the IFLS data in the year of 1997, 2000, and 2007.

This paper is started with an introduction, then in the second part it will discuss about formal schools condition in Indonesia, the third section explains the model being used, the fourth section presenting data used in the empirical study, the fifth section describes the empirical data, the sixth section provides an explanation on the empirical results, and the last part, the seventh section, is the conclusion.

\section{FORMAL SCHOOL IN INDONESIA}

Generally speaking, education in Indonesia can be divided into formal, non-formal, and informal education. Formal education is one that is held at schools in general. Nonformal education, on the other hand, is mostly available for early age and elementary, and also religious learning (Tempat Pembelajaran Al'Quran/TPA) held in mosques or Sunday school in churches. Meanwhile, informal education is education acquired from families and surroundings in the form of independent learning conducted consciously and responsibly.

Based on the Education acts number No. 20/2003, the formal school system in Indonesia consists of five levels. First, two years of Kindergarten, then 6 years of Primary School (Sekolah Dasar/SD) and 3 years of Junior Secondary School (Sekolah Menengah Pertama/SMP), next is 3 years of Senior Secondary School (Sekolah Menengah Atas/SMA), followed by tertiary education consisting of Diploma and Bachelor which normally takes between 1 and 5 years, and the fifth is the highest level of education i.e. Master and Doctoral.

Table 1. Net Enrollment Rate, from 2003 to 2011

\begin{tabular}{|l|c|c|c|c|c|c|c|c|c|}
\hline Level & $\mathbf{2 0 0 3}$ & $\mathbf{2 0 0 4}$ & $\mathbf{2 0 0 5}$ & $\mathbf{2 0 0 6}$ & $\mathbf{2 0 0 7}$ & $\mathbf{2 0 0 8}$ & $\mathbf{2 0 0 9}$ & $\mathbf{2 0 1 0}$ & $\mathbf{2 0 1 1}$ \\
\hline Primary School & 92.55 & 93.04 & 93.25 & 93.54 & 93.78 & 93.99 & 94.37 & 94.76 & 91.03 \\
\hline Junior Secondary Sch. & 63.49 & 65.24 & 65.37 & 66.52 & 66.9 & 67.39 & 67.43 & 67.73 & 68.12 \\
\hline Senior Secondary Sch. & 40.56 & 42.96 & 43.5 & 43.77 & 44.84 & 44.97 & 45.11 & 45.59 & 47.97 \\
\hline
\end{tabular}

Source: BPS-RI, Susenas 2003-2011 
To improve the living standard of their people, the current government requires all people aged 7-12 and 12-15 years old to finish their 9-year primary study with the arrangement of 6 years in primary school (SD) and 3 years in Junior Secondary School (in the Constitution of National Education No. 2/1989, the so-called 9 Years Compulsory Education (Wajib Belajar 9 tahun)). Referring to table 1 regarding the net enrollment rate taken from the Central Office of Statistic (BPS) based on SUSENAS 2003-2011, it can be seen that the number of participation for Primary School was already above 90 \%, which is also supported by the program of developing several Primary Schools in 1974/1975 through Inpres Program which quite succeeded in increasing the participation of Indonesian children aged 7-12 years old to go to school (see Duflo, 2001). Nevertheless, in the level of Junior Secondary School, the rate of participation is still of main concern i.e. below $70 \%$. The main reason for this is the lack of school infrastructures for Junior Secondary School. Until recently, there are still several villages in Indonesia, especially in the remote areas which yet have school infrastructures at the level Junior Secondary School and above.

Therefore, the goal of the government cannot be achieved soon without any help from the society in establishing educational institutions or private schools. An increase in private schools should also be the concern of the government so that the education quality can be maintained. One of the efforts to maintain the standardized quality by the government is by organizing the standardized National Exam for the level of Primary School (SD), Junior Secondary School (SMP) and Senior Secondary School (SMA) according to the Education acts No 20/2003.

In public school, the financing, regulation, and standard are mostly determined by the government. Most of the public schools are common schools whereas most of private schools are religious ones either Islam or Christian/Catholic. The education system of the public schools is organized by the Ministry of Education and Culture while the system for religious ones especially Islam or known as Madrasah is managed by the Ministry of Religion. 40\% of Madrasah School's curriculum is generally of religious content, while the remaining $60 \%$ is in accordance to public schools as arranged by the Ministry of Education and Culture. 
Table 2. The Number of Public and Private Junior Secondary Schools

\begin{tabular}{|c|c|c|c|c|c|c|c|c|}
\hline Province & Public & Private & Public & Private & Public & Private & Public & Private \\
\hline & \multicolumn{2}{|c|}{2006} & \multicolumn{2}{|c|}{2007} & \multicolumn{2}{|c|}{2008} & \multicolumn{2}{|c|}{2009} \\
\hline WEST JAVA & 1295 & 1588 & 1302 & 1558 & 1594 & 1887 & 1564 & 1863 \\
\hline BANTEN & 289 & 447 & 334 & 484 & 356 & 608 & 409 & 623 \\
\hline CENTRAL JAVA & 1552 & 1252 & 1608 & 1259 & 1644 & 1279 & 1720 & 1289 \\
\hline EAST JAVA & 1400 & 1839 & 1449 & 1793 & 1537 & 1915 & 1592 & 1999 \\
\hline JAKARTA & 310 & 658 & 310 & 662 & 310 & 714 & 310 & 714 \\
\hline ACEH & 517 & 98 & 583 & 116 & 648 & 138 & 689 & 169 \\
\hline $\begin{array}{l}\text { NORTH } \\
\text { SUMATRA }\end{array}$ & 780 & 1038 & 886 & 1184 & 1003 & 1097 & 1048 & 1135 \\
\hline $\begin{array}{l}\text { WEST } \\
\text { SUMATRA }\end{array}$ & 435 & 87 & 483 & 90 & 555 & 96 & 578 & 101 \\
\hline RIAU & 432 & 212 & 514 & 240 & 578 & 242 & 596 & 257 \\
\hline JAMBI & 339 & 101 & 387 & 93 & 443 & 76 & 464 & 86 \\
\hline $\begin{array}{l}\text { SOUTH } \\
\text { SUMATRA }\end{array}$ & 502 & 426 & 577 & 402 & 691 & 388 & 728 & 399 \\
\hline LAMPUNG & 378 & 542 & 451 & 583 & 540 & 604 & 568 & 640 \\
\hline $\begin{array}{l}\text { WEST } \\
\text { KALIMANTAN }\end{array}$ & 431 & 337 & 488 & 347 & 607 & 346 & 655 & 340 \\
\hline $\begin{array}{l}\text { SOUTH } \\
\text { KALIMANTAN }\end{array}$ & 359 & 56 & 421 & 62 & 454 & 64 & 469 & 61 \\
\hline $\begin{array}{l}\text { EAST } \\
\text { KALIMANTAN }\end{array}$ & 322 & 175 & 358 & 179 & 431 & 177 & 443 & 181 \\
\hline $\begin{array}{l}\text { NORTH } \\
\text { SULAWESI }\end{array}$ & 303 & 261 & 302 & 261 & 357 & 238 & 365 & 246 \\
\hline $\begin{array}{l}\text { CENTRAL } \\
\text { SULAWESI }\end{array}$ & 316 & 97 & 352 & 98 & 378 & 97 & 379 & 102 \\
\hline $\begin{array}{l}\text { SOUTH } \\
\text { SULAWESI }\end{array}$ & 693 & 273 & 766 & 291 & 839 & 339 & 873 & 336 \\
\hline $\begin{array}{l}\text { WEST } \\
\text { SULAWESI }\end{array}$ & 102 & 38 & 117 & 40 & 167 & 49 & 183 & 47 \\
\hline $\begin{array}{l}\text { NORTH } \\
\text { MALUKU }\end{array}$ & 108 & 102 & 108 & 102 & 143 & 100 & 154 & 100 \\
\hline BALI & 190 & 129 & 223 & 173 & 210 & 136 & 220 & 141 \\
\hline NTB & 319 & 69 & 370 & 72 & 406 & 95 & 417 & 106 \\
\hline
\end{tabular}

Source : www.psp.kemendiknas.go.id

The type of school in Indonesia especially in the level of junior high school can be categorized into general public school, Islamic public school (Madrasah), general private school (secular), Islam private school, Christian private school, Catholic private school, and Hindu-Budha private school. In this paper, due to the limitation of data availability for some types of school, the existing type of school will only be grouped into four, i.e. 
public school (general public and Islam public), private secular, Islam private, and nonIslam private (Christian private, catholic Private, and Hindu-Budha private).

The number of both public and private junior high schools in every province experiences an annual increase (Table 2). From table 2, it can be seen that there are some provinces that have more public schools than private schools such as Central Java, Aceh, West Sumatera, Riau, and Jambi. However, there are also provinces with the opposite trend like Jakarta, West Java, Banten, East Java, North Sumatera, and Lampung.

Table 3. The Number of Public and Private Junior Secondary School Students

\begin{tabular}{|l|c|c|c|}
\hline \multicolumn{1}{|c|}{ Province } & Public & Private & Ratio \\
\hline WEST JAVA & 970,515 & 454,805 & 2.13 \\
\hline BANTEN & 210,460 & 149,619 & 1.41 \\
\hline CENTRAL JAVA & 964,581 & 299,195 & 3.22 \\
\hline EAST JAVA & 853,339 & 339,005 & 2.52 \\
\hline JAKARTA & 242,954 & 139,806 & 1.74 \\
\hline ACEH & 199,388 & 14,475 & 13.77 \\
\hline NORTH SUMATRA & 417,528 & 241,980 & 1.73 \\
\hline WEST SUMATRA & 197,398 & 12,447 & 15.86 \\
\hline RIAU & 152,033 & 40,869 & 3.72 \\
\hline JAMBI & 97,035 & 13,517 & 7.18 \\
\hline SOUTH SUMATRA & 239,592 & 78,076 & 3.07 \\
\hline LAMPUNG & 188,248 & 113,606 & 1.66 \\
\hline WEST KALIMANTAN & 130,776 & 55,251 & 2.37 \\
\hline SOUTH KALIMANTAN & 99,857 & 9,071 & 11.01 \\
\hline EAST KALIMANTAN & 120,894 & 25,621 & 4.72 \\
\hline NORTH SULAWESI & 75,291 & 31,260 & 2.41 \\
\hline CENTRAL SULAWESI & 106,480 & 4,478 & 23.78 \\
\hline SOUTH SULAWESI & 277,158 & 53,153 & 5.21 \\
\hline WEST SULAWESI & 42,793 & 4,952 & 8.64 \\
\hline NORTH MALUKU & 30,452 & 13,299 & 2.29 \\
\hline BALI & 124,635 & 42,488 & 2.93 \\
\hline NTB & 154,450 & 9,999 & 15.45 \\
\hline
\end{tabular}

Source : www.psp.kemendiknas.go.id

Moreover, table 3 shows the number of Junior High School students in 2009, in which the number of public school students was more than those of private school. It indicates that the percentage of public school students is higher than those of private schools in all provinces although the number of private school is more than the number 
of public school in the province. This can be seen from the number ratio of public school students compared to private school students in all provinces was above one (see table 3). The smallest ratio is found in the province of Banten, that is, 1.41 while the biggest ratio is the province of Southeast Sulawesi with 23.78. This tendency implies that the number of students in the public school is higher than those of private.

The first advantage of public schools is its affordable cost. After the School Operational Aid program of Bantuan Operasional Sekolah/BOS in July 2005, Junior Secondary School tution fees is generally free. Secondly, teachers of public schools have a stable income and they are categorized as civil servant (Pegawai Negeri Sipil/PNS), while the third benefit is that the rules and standards are given by the government so that parents are not too much need to involve in the students' operational activities. On the other side, the positive values of private school are that the bigger ratio between students and teachers, the smaller number of students in the class, thereby it is easier for teachers to deliver the lessons. The regulations in private schools are also more flexible so a necessary curriculum can be easily added.

\section{DATA}

The data used in this study were taken from Indonesian Family Life Survey (IFLS) in the year of 1997, 2000 and 2007. IFLS is major scale longitudinal observational data from an individual and household level for the purpose of socio-economic and health survey. IFLS sampling was first collected in 1993 and collected in the provincial level in which samples were randomly selected. Due to the limited funding, there were only 13 provinces selected out of 26 total in Indonesia. However, these 13 provinces included $83 \%$ of Indonesia's total population. In 1993, IFLS was not used in this study because by then, it did not have national exit exam score records.

The data were restricted to respondents who reported their National Exit Exam scores (what used to be Ebtanas Scores) in the 1995 Junior High School exam and thereafter. Respondents reporting their scores at both levels, i.e. Primary School and Junior Secondary School were selected as the samples of this study. Since there was a discrepancy in the number of subjects tested in the Ebtanas (now-called National Exit Exam), an approximation method of the average National Exit Exam Scores (Nilai Ebtanas Murni/NEM) was used in this study. 
In 1997 and 2000 IFLS, there were no questions on how many subjects tested in the Ebtanas, so that an average proxy of NEES was created by taking 3 main subjects (Pancasila-Indonesian Values and Ideology/PPKN, Indonesian Language, and Mathematics). These three subjects were chosen because they were annually tested in every level of education (until 2007). Therefore, for the 2007 IFLS, this study used the same proxy as 1997 and 2000 IFLS data. As a result, the sample data contains 4,550 respondents which consisted of 762 of 1997 IFLS respondents, 982 of 2000 IFLS respondents, and the remaining 2.806 of 2007 IFLS respondents

Table 4. Definition and Descriptive Statistics

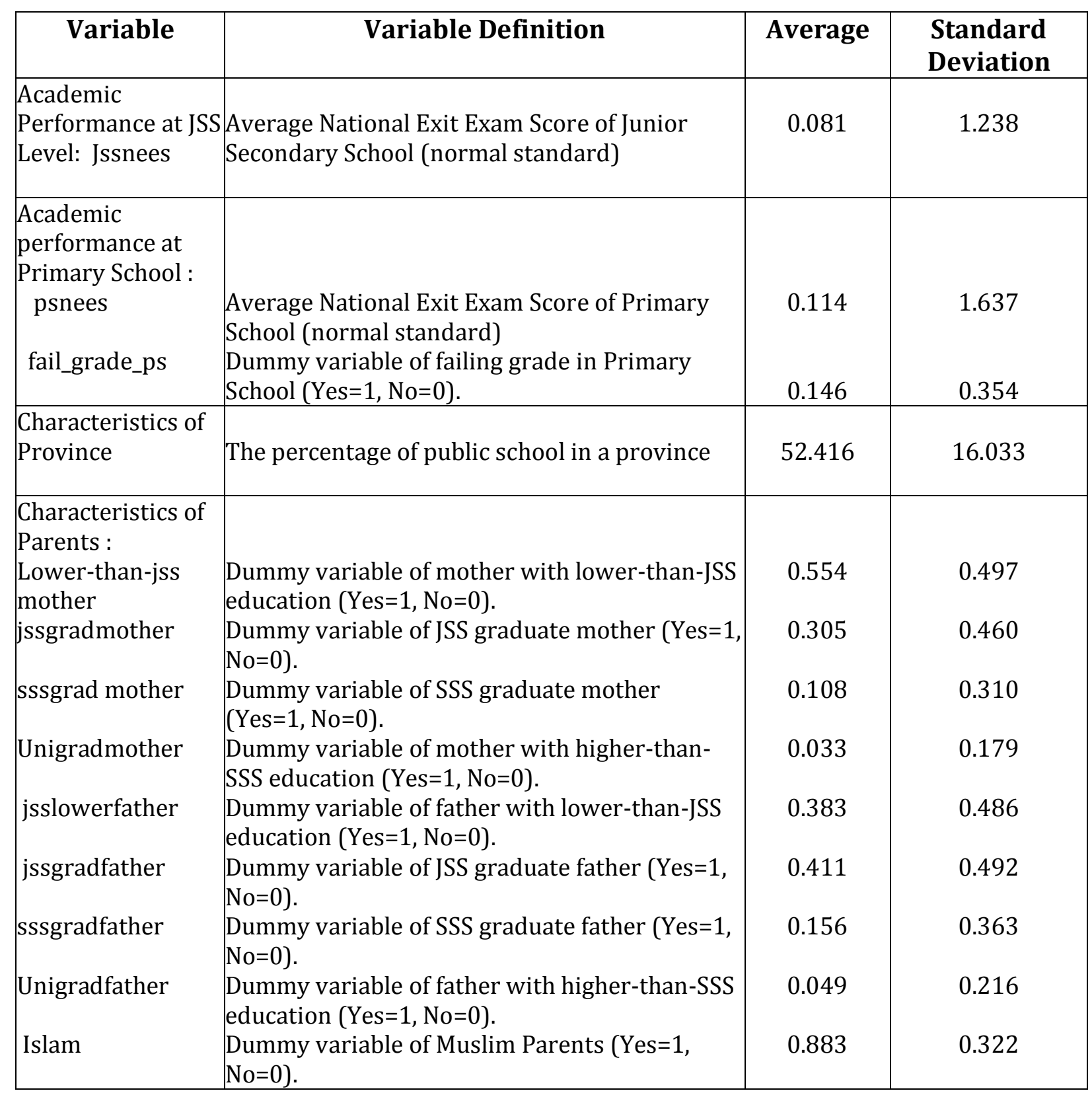




\begin{tabular}{|c|c|c|c|}
\hline \multicolumn{4}{|l|}{$\begin{array}{l}\text { Characteristics of } \\
\text { Students: }\end{array}$} \\
\hline Sex & Dummy variable of male sex $(Y e s=1, N o=0)$ & 0.465 & 0.499 \\
\hline Work_jss & $\begin{array}{l}\text { Dummy variable of working during SMP study } \\
(Y e s=1, N o=0) \text {. }\end{array}$ & 0.065 & 0.246 \\
\hline r_village & $\begin{array}{l}\text { Dummy variable of living in the village up to } 12 \\
\text { years old }(Y e s=1, N o=0) \text {. }\end{array}$ & 0.591 & 0.492 \\
\hline r_stown & $\begin{array}{l}\text { Dummy variable of living in small town up to } 12 \\
\text { years old }\left(Y e s=1, N_{0}=0\right)\end{array}$ & 0.271 & 0.445 \\
\hline r_bcity & $\begin{array}{l}\text { Dummy variable of living in big cities up to } 12 \\
\text { years old }\left(Y e s=1, N_{0}=0\right)\end{array}$ & 0.138 & 0.344 \\
\hline \begin{tabular}{|l|} 
Type of Primary \\
School: \\
schooltype_ps \\
1. \\
2. \\
3. \\
4. \\
\end{tabular} & $\begin{array}{l}\text { Variable of category } \\
\text { Public PS } \\
\text { Private secular PS } \\
\text { Private Islamic PS } \\
\text { Private Non-Islamic PS }\end{array}$ & 1.254 & 0.700 \\
\hline Type of JSS & & & \\
\hline Publicjss & Dummy variable of public JSS (Yes=1, No=0). & 0.700 & 0.458 \\
\hline Privatejss & $\begin{array}{l}\text { Dummy variable of private secular JSS (Yes=1, } \\
\text { No=0). }\end{array}$ & 0.120 & 0.326 \\
\hline Islamicjss & $\begin{array}{l}\text { Dummy variable of Private Islamic JSS (Yes=1, } \\
\text { No=0). }\end{array}$ & 0.161 & 0.367 \\
\hline Non-islamicjss & $\begin{array}{l}\text { Dummy variable of Private Non-Islamic JSS } \\
(\text { Yes=1, No=0). }\end{array}$ & 0.026 & 0.160 \\
\hline $\begin{array}{l}\text { Language } \\
\text { IndoLang }\end{array}$ & $\begin{array}{l}\text { Is Indonesian Language used in daily activities } \\
\text { at home }\left(\mathrm{Yes}=1, \mathrm{~N}_{\mathrm{o}}=0\right) \text {. }\end{array}$ & 0.316 & 0.465 \\
\hline $\begin{array}{l}\text { Household Welfare } \\
\text { Lnpce }\end{array}$ & $\begin{array}{l}\text { Log natural person consumption expenditure } \\
\text { (rupiah) }\end{array}$ & 12.586 & 0.899 \\
\hline Type of Floor & & & \\
\hline Tile_floor & Dummy variable of Tile floor $(Y e s=1, \mathrm{No}=0$ ). & 0.215 & 0.411 \\
\hline Cement_floor & Dummy variable of Cement floor (Yes $=1, \mathrm{No}=0$ ). & 0.323 & 0.468 \\
\hline Lumber_floor & Dummy variable of Lumber floor $(\mathrm{Yes}=1, \mathrm{No}=0)$. & 0.094 & 0.292 \\
\hline Bamboo_floor & $\begin{array}{l}\text { Dummy variable of Bamboo floor (Yes=1, } \\
\text { No=0). }\end{array}$ & 0.002 & 0.042 \\
\hline Dirt_floor & Dummy variable of Dirt floor (Yes $=1, \mathrm{No}=0$ ). & 0.051 & 0.219 \\
\hline Ceram_floor & $\begin{array}{l}\text { Dummy variable of Ceramics floor (Yes=1, } \\
\text { No=0). }\end{array}$ & 0.315 & 0.465 \\
\hline $\begin{array}{l}\text { Location of } \\
\text { Residence }\end{array}$ & & & \\
\hline Java-Bali & $\begin{array}{l}\text { Dummy variable of living in Java and Bali } \\
(\text { Yes }=1, \text { No=0). }\end{array}$ & 0.619 & 0.486 \\
\hline $\begin{array}{l}\text { travellingtime_ } \\
\text { smp }\end{array}$ & $\begin{array}{l}\text { The amount of time needed to travel to school } \\
\text { in minute }\end{array}$ & 19.080 & 8.223 \\
\hline $\mathrm{N}$ & Total of Observation & 4550 & \\
\hline
\end{tabular}

Notes: jss (junior secondary school), nees (national exit exam score), ps (primary school), sss (senior secondary school), jssgradmother (junior secondary school graduate mother).

Source: Indonesian Family Life Survey (IFLS). 
Table 4 demonstrates the variables used in this study along with its statistical summary. National Exit Exam scores were made in the standard score with an average of 0 , and deviation standard of 1 . In general, there were $14.6 \%$ of students who were not continued to higher grade (drop out) while they were in Primary School. The average percentage of public school in each province was 52.4\%. Mothers' educational background remains quite low where $55.4 \%$ of them never attended junior high school, $30.5 \%$ graduated from junior high school, $10.8 \%$ of high school, and the rest $3.3 \%$ of universities. In the mean time, fathers had slightly higher educational background with 38.3 never attended junior high school education, $41.1 \%$ finished junior high school, $15.6 \%$ of senior high school, and the remaining $4.9 \%$ of universities. Most of the respondents were Muslims (88.3\%) while 1.7\% consisted of Christian, Catholic, Hindu, and Budha. There were $46.5 \%$ male respondents and others were females. Most of the respondents lived in the countryside or rural areas at the age of 12 (59.1\%). Regarding the type of school, 70\% came from public school, 12\% from secular private school, $16.1 \%$ from Private Islamic school, and only $2.6 \%$ from private non-Islamic school.

\section{ECONOMETRICS MODEL}

A simple model to find out the effect of school type on the National Exit Exam Scores of Junior High School students is as shown in Newhouse and Beegle (2006):

$$
\text { jssnees }_{i}=\beta_{g} X_{i}+\gamma T_{i}+\varepsilon_{i}
$$

The above model contains two sources of selection bias; first, the non-random decisions in determining a school type where there is a minimum passing grade in every public school based on the scores from Primary School, so that there is a higher perception toward public schools. Secondly, wealthy families prefer to put their children to private school, ceteris paribus.

As in Newhouse and Beegle (2006), the description of utility functions of parents in deciding the type of school uses two-period model where in the first period parents choose the school and in the second the children will transfer their opinions based on the education quality. The functions of parents' utility are in the form of:

$$
U_{j}=\ln \left(Y_{1}-P_{j}\right)+\delta \ln \left(Y_{2}+T r_{j}\right)+\sigma T r_{j}+\gamma O_{j}
$$

where $Y_{t}$ represents the household income in $\mathrm{t}$ which is exogenous to school type. $P_{j}$ represents teaching at school $\mathrm{j}$, and $\delta$ represents parents' discount rate. $\operatorname{Tr}_{j}$ refers to 
students' transfer to their parents by the end of period 1 after attending school $\mathrm{j} . O_{j}$ represents characteristics of non-academic schools according to parents such as safety, additional religious course, facilitation, and discipline.

In the second period, students' transfer function is assumed to be positive and linear with three determinants, i.e. quality of schools $\left(Q_{j}\right)$, parents' income in period $1\left(Y_{1}\right)$, and students' effort or ability (E). The function of transfer is formulated:

$$
T_{j}=Q_{j}+a Y_{1}+b E .
$$

With an assumption that parents, whose income is higher, will provide a better study environment, the parameter from a is expected to be positive. Other required assumptions are that $\sigma$ which is the standard of parents' preference to education is positive, and household income $Y_{t}$ is higher than school fee $P_{j}$ for all school j.

The decision on the choice of school which can be attended by students is restricted by the students' house location (residence) and the result of national exit exam (used to be called as Ebtanas) from Primary School. The presence of these limitations and non-academic characteristic of the school $O_{j}$ can lead parents to select private schools even though there is a public school with high quality. Parents will choose the public school provided that the maximum utility of the public school $U_{\text {public }}^{*}$ exceeds that of private school $U_{\text {private }}^{*}$ The different utilities of public and private school are:

$$
\begin{aligned}
& \Delta U^{*} \ln =\ln \left(Y_{1}-P_{\text {public }}\right)-\ln \left(Y_{1}-P_{\text {private }}\right)+\delta \ln \left(Y_{2}+T_{\text {public }}\right)-\delta \ln \left(Y_{2}+T_{\text {private }}\right)+ \\
& \sigma\left(T_{\text {public }}-T_{\text {private }}\right)+\gamma\left(O_{\text {public }}-O_{\text {private }}\right)
\end{aligned}
$$

\section{Empirical Strategy}

National Exit Exam Scores (used to be NEM) both in the level of Elementary (Primary School) and Junior Secondary were made into standard score with 0 average (median) and standard deviation of 1 for all students taking exam in the same year. Many of IFLS respondents had graduated a few years before so that such household characteristics as household consumption was not observed when they join in the National Exam. Thus, this study limits the exam year of Junior Secondary School after 1995, in order to make it closer to the 1997 IFLS data. 
OLS model of the National Exit Exam Score (nees) depended upon the characteristics of students and their household as well as type of school in the level of Junior Secondary School:

$$
\text { jssnees }_{\mathrm{i}}=\beta_{s} X_{i}+\gamma T_{i}+\varepsilon_{i}
$$

where $X_{i}$ is vector for students' characteristics i and their varied household backgrounds in the samples. $T_{i}$ is vector for school type attended by students (public or private).

One of the techniques to overcome bias on the OLS model above is by using fixed effect (FE). With the assumption that parents have the same preference in choosing school for their children (time-invariant), household fixed effect is used. Fixed effect model by adding household characteristics made the model specification into:

$$
\text { jssnees }_{h, i}=\beta_{f} X_{h_{h} i}+\gamma T_{h_{i} i}+\delta_{h}+\varepsilon_{h, i}
$$

in which household h consisted of all students with the same mothers and fathers.

Another technique that can be used to cope with the bias in OLS is by employing the method of instrument variable (IV). Difficulty in choosing instrument became an obstacle in the use of this technique. To work well, the instrument should be exogenous and does not affect the outcome directly, and there must be relationship between instrument and an endogenous independent variable by testing it using statistic test $\mathrm{F}$ in the first stage. To obtain an estimation of instrument variable, the first stage of variable estimation of school type used the model of:

$$
T_{i}=\beta_{t} X_{i}+\delta W_{i}+u_{i}
$$

of this, $W_{i}$ is the percentage of public school in the province and year where and when the students took their junior secondary school. This estimation was then inputed to the second equation of OLS called as the second stage. In this study, what served as the instrument is the percentage of exogenous public schools, because rationally the percentage of public school is exogenous, thereby did not directly affect the NEES scores. Meanwhile, to find out whether there was a relationship between the percentage of public school and the school type, it can be seen from test $F$ which had to be significant and had value above 10 . 
As for the control variables used in this model are:

a. Academic achievement at the primary level. This variable consisted of Primary National Exit Exam Score (NEES) which were made in standard score and dummy variable whether students once failed a subject during primary school.

b. Family background. The selected variable to see the family background was the parents' educational background, the family religion, and the language used in daily activities.

c. Characteristics of location (residence). This variable comprised the province where the student lived, and whether at the age of 12 they lived in the countryside, small town, or big cities.

d. School type of the Primary School. This variable was in the form of multinomial where the type of school was divided into public school, private school, Islamic private school, and non-Islamic private school.

e. Characteristics of students. This variable consisted of dummy variable of sex, and whether they were working while studying in the Junior Secondary School.

\section{EMPIRICAL RESULTS}

\section{Determinant of School Type}

Determination on school type is one of the causes of selection bias in the issue of the school type effect on the academic scores. Public schools which are generally regarded superior compared to private schools motivated students to be part of them. The presence of minimum grade of Primary School Final Exam as the prerequisite of entering public schools was the reason for the non-random selection of school type. In the mean time, provided that the condition of other individual and household characteristics were considered constant, the wealthier ones tended to put their children to private school which offered more comfort, additional religious lesson, and discipline. To explain the effect of household prosperity and students' academic performance to their chosen type of school, regression estimation of multinomial logit was used in the JSS type. There were 4 school types used i.e. public JSS, common private, Islamic Private, and Non-Islamic private. Public JSS was further divided into common public school and Islamic public school. Non-Islamic private school was dominated by Christian and Catholic schools. 
Table 5 is the result of multinomial logit regression estimation to decide the type of junior secondary school. Public schools serve as the base outcome. The whole set of household and individual characteristics are used as the control variables, though only variables of household welfare, academic performance during Primary School, and parents' education are depicted in table 5. The significant variable mainly includes family welfare which can be seen from consumption outcome per capita and the kind of floor used. National Exit Exam Score from Primary School is also a determinant in selecting the type of school a student wants to join.

The obtained iteration $\log$ result indicates how fast the convergence of the model is. To attain the convergent model, it is required 12 iterations with the value of $\log$ likelihood (-3428.3404). 48.23 Likelihood ratio chi-square with a $p$-value $<0.0000$ shows that this model is generally significantly better than the null model or a model without predictors. The output of multinomial logit model has three sections from the category label outcome variable of junior secondary school type appropriate with the following equations:

$$
\begin{aligned}
& \ln \left(\frac{\left.P\left(\text { schooltype }_{j s s}=\text { secular private }\right)\right)}{P\left(\text { schooltype }_{j s s}=\text { public }\right)}\right) \beta_{10}+\sum \beta_{1 j} X_{j} \\
& \ln \left(\frac{P\left(\text { schooltype }_{j s s}=\text { islamic private }\right)}{P\left(\text { schooltype }_{j s s}=\text { public }\right)}\right)=\beta_{20}+\sum \beta_{2 j} X_{j} \\
& \ln \left(\frac{P\left(\text { schooltype }_{j s s}=\text { nonislamic private }\right)}{P\left(\text { schooltype }_{j s s}=\text { public }\right)}\right)=\beta_{30}+\sum \beta_{3 j} X_{j}
\end{aligned}
$$

A $10 \%$ increase in the variable of consumption outcome per capita (pce) in relation to the decrease in relative $\log$ odds of choosing private schools rather than public schools is as much as 0.202 , while the declining relative log odds in selecting Islamic private schools compared to public schools is 0.129 , both of which are significant at the level of $1 \%$ and $5 \%$ respectively. Meanwhile, both public schools and non-Islamic private schools have positive but not significant. It can be defined that relative risk ratio for a $10 \%$ increase in the pce variable is $0.817(\exp (-0.202)$, exponent number obtained from the coefficient estimation of multinomial logit) for students preferring private schools to public schools, and as much as 0.825 (exp(-0.192)) for students choosing Islamic private schools over public schools. In simple words, a 10\% 
increase of variable pce decreases $18.3 \%$ students choosing private school and $17.5 \%$ students selecting Islamic schools rather than public schools.

Table 5. Model Estimation of Multinomial Logit of Junior Secondary School Type

\begin{tabular}{|l|c|c|c|}
\hline & Secular Private & Islamic Private & Non Islamic Private \\
\hline Family Welfare & $-0.202^{* * *}$ & $-0.129^{* *}$ & 0.002 \\
Lnpce & $0.263^{*}$ & 0.065 & 0.310 \\
Tile_floor & 0.172 & -0.006 & 0.556 \\
Cement_floor & $-0.616^{* * *}$ & $-0.678^{* * *}$ & 0.648 \\
Lumber_floor & 1.218 & 0.247 & -8.485 \\
Bamboo_floor & 0.340 & $0.322^{*}$ & 1.027 \\
Dirt_floor & & & \\
\hline Academic Performance & $-0.287^{* * *}$ & $-0.443^{* * *}$ & -0.362 \\
Psnees & $0.252^{* *}$ & 0.069 & 0.076 \\
Fail_grade_ps & & & -0.066 \\
\hline Parent Characteristics & 0.048 & -0.024 & 0.392 \\
Jssgradmother & -0.291 & 0.026 & 0.331 \\
Sssgradmother & -0.578 & $-0.776^{*}$ & $0.585^{*}$ \\
Unigradmother & 0.058 & -0.094 & $0.690^{*}$ \\
Jssgradfather & -0.137 & $-0.443^{* * *}$ & 0.682 \\
Sssgradfather & -0.441 & $-0.697^{* *}$ & 4550 \\
Unigradfather & 4550 & 4550 & 0.1 \\
\hline Observation &
\end{tabular}

Notes: *significance of $10 \%,{ }^{* *}$ significance of $5 \%$ and ${ }^{* * *}$ significance of $1 \%$. The category serving as base outcome is public junior secondary school. This regression involves not only above variables but also other control variables: religion (dummy: $1=$ Islam 0 =non-Islam), sex (dummy: 1 =male 0 =female), working during studying (dummy: $1=$ working $0=$ not working), indicator of language used at home (using Indonesian Language or not), domicile before 12 years old(divided into 4 categories), province of residence (divided into Java-Bali and outside) and school type during Primary School (divided into 4 categories).

Source: Author Calculations

An increase of one deviation standard in the Primary School's National Exit Exam Result is related to the decrease of relative log odds between private schools and public school as much as 0.287 . The decrease of relative $\log$ odds between Islamic private schools and public schools is 0.443 , both of which are significant in the level of $1 \%$. Meanwhile, although the comparison between public schools and non-Islamic Private schools is insignificant, it has similar characteristics to the other two types of schools. It demonstrates that students with high National Exit Exam scores (Primary) tend to choose public schools. In the form of relative risk ratio, an increase of one deviation standard of NEES scores is equal to 0.751 for those choosing private schools over public schools and equal to 0.642 for those choosing Islamic private schools over public 
schools. In other words, a one deviation standard increase in the Primary School National Exit Exam scores reduces 24.9\% students preferring private schools and $35.8 \%$ students choosing for Islamic private schools over public schools.

Relative Log odds of being in a private school rather than public school will rise by 0.252 for students failing their subjects during primary study compared to students who have never failed. Relative risk ratio of students who once failed a subject is 1.287 for those preferring private schools to public schools. In other words, students who once failed a subject have an increase in the probability of choosing private schools as much as $28.7 \%$ compared to those who never failed. Comparison between public schools, Islamic private schools, and non-Islamic private schools for the failing subject variable has positive but insignificant characteristics.

In the mean time, for variables of parents' education, the significance can only be found in the type of private Islamic schools. Parents (father or Mother) with higher education level generally decrease the probability of choosing private Islamic schools in comparison to public schools.

\section{The Effect of Public Schools on National Exit Exam Scores (NEES)}

This section answers the question whether public schools or private ones generally improve the National Exit Exam Scores in the level of Junior Secondary School. First, NEES regression is used with control variables mentioned above and types of school serving as dummy variable. The regression result is presented in table 6 where only a few variables shown to focus on interest of independent variables. Table 6 is an estimation result using the method of OLS and fixed effect. Meanwhile, variable instrument method is shown in table 7.

The empirical result in table 6 shows that public junior high school affects students' scores positively. With the OLS result, it can be stated that students of public junior high schools have a 0.3 higher of standard deviation in the average National Exit Excam score than that of private schools. The use of fixed effect method results in the representation that students of public junior high schools have a 0.247 higher of standard deviation in the average National Exit Exam score than that of private junior high schools. Both results show that the resulted estimation by OLS has a higher tendency, and bias selection is upward. 
Table 6. The Effect of Public Junior High School on National Exit Exam Scores

\begin{tabular}{|c|c|c|}
\hline & $\begin{array}{c}\text { OLS } \\
\text { Jsssnees }\end{array}$ & $\begin{array}{c}\text { FE } \\
\text { Jssnees }\end{array}$ \\
\hline & b/se & b/se \\
\hline Publicjss & $\begin{array}{c}0.300^{* * *} \\
(0.04)\end{array}$ & $\begin{array}{c}0.247^{*} \\
(0.099)\end{array}$ \\
\hline Lnpce & $\begin{array}{c}0.084^{* * *} \\
(0.023)\end{array}$ & $\begin{array}{l}0.161^{* *} \\
(0.058)\end{array}$ \\
\hline Psnees & $\begin{array}{c}0.131^{* * *} \\
(0.011)\end{array}$ & $\begin{array}{l}0.048^{* *} \\
(0.018)\end{array}$ \\
\hline fail_grade $\sim$ ps & $\begin{array}{c}-0.191^{* * *} \\
(0.05)\end{array}$ & $\begin{array}{l}-0.077 \\
(0.111)\end{array}$ \\
\hline $\begin{array}{l}\text { Jssgrad } \\
\text { mother }\end{array}$ & $\begin{array}{l}0.124^{* *} \\
(0.046)\end{array}$ & $\begin{array}{c}0.185 \\
(0.158)\end{array}$ \\
\hline $\begin{array}{l}\text { Sssgradmothe } \\
\mathrm{r}\end{array}$ & $\begin{array}{l}0.219 * * \\
(0.071)\end{array}$ & $\begin{array}{l}0.162 \\
(0.25)\end{array}$ \\
\hline $\begin{array}{l}\text { Unigradmothe } \\
\mathrm{r}\end{array}$ & $\begin{array}{l}0.333^{* *} \\
(0.113)\end{array}$ & $\begin{array}{c}-0.26 \\
(0.451)\end{array}$ \\
\hline Jssgradfather & $\begin{array}{c}0.172^{* * *} \\
(0.045)\end{array}$ & $\begin{array}{c}0.24 \\
(0.142)\end{array}$ \\
\hline Sssgradfather & $\begin{array}{c}0.063 \\
(0.062)\end{array}$ & $\begin{array}{c}0.375 \\
(0.225)\end{array}$ \\
\hline Unigradfather & $\begin{array}{c}0.197^{*} \\
(0.098)\end{array}$ & $\begin{array}{c}-0.142 \\
(0.362)\end{array}$ \\
\hline $\begin{array}{l}\text { Sex } \\
\text { cons }\end{array}$ & $\begin{array}{c}-0.137^{* * *} \\
(0.035) \\
-1.284^{* * *} \\
(0.305)\end{array}$ & $\begin{array}{c}-0.253^{* * *} \\
(0.073)\end{array}$ \\
\hline $\begin{array}{l}\text { R-squared } \\
N\end{array}$ & $\begin{array}{l}0.105 \\
4550\end{array}$ & $\begin{array}{l}0.185 \\
1973\end{array}$ \\
\hline
\end{tabular}

Notes: *significance of $10 \%,{ }^{* *}$ significance of $5 \%$ and ***significance of $1 \%$. Other control variables included in equation are the type of floor, working during junior high school study, duration of jhs study, language used daily, place of residence at 12 years old, province of residence, school type at SD

Some control variables for both methods, i.e. OLS and FE are equally significant and have similar coefficient characteristics such as outcome per capita (pce), national exit exam scores for Primary School, and sex. Every 1\% change in pce is related to the average change in the NEM scores as much as 0.00084 standard deviation for the OLS 
method and 0.00161 standard deviation for the FE method. Every one standard deviation rise in the National Exit Exam scores increases the average National Exit Exam scores as much as 0.131 standard deviation for the OLS method and 0.048 standard deviation for the FE method. Male students have a 0.137 and 0.253 smaller standard deviation in the National Exit Exam scores compared to the female ones for the OLS and FE methods respectively.

The non-random students in following various choices of school types can be the potential source of bias. This matter can be overcome, however, by using two-stageleast-square model in the National Exit Exam scores by making instrument measurement for the public school type. This approach was also applied by Newhouse and Beegle (2006) for the same case and by Neal (1997) as well as Figlio and Ludwig (2000) when they estimated the effects of Catholic schools in the USA.

\section{Table 7. The Effect of Public Junior High School on National Exit Exam Scores with Instrument Variable}

\begin{tabular}{l|l|c|}
\hline & $\begin{array}{c}\text { IV } \\
\text { jssnees } \\
\text { b/se }\end{array}$ \\
\hline Publicjss & $0.572^{*}$ \\
$(0.293)$ & \\
First Stage Result & 23.96 \\
F Statistic & 0.0186 \\
R-square partial & 4550 \\
\hline $\begin{array}{l}\text { Observation } \\
\text { R-square }\end{array}$ & 0.104 \\
\hline Notes: *significance of 10 \%, ** significance of 5 \% and \\
***significance of 1 \%. All control variables discussed \\
are included in the equation. \\
Source: Author Calculation
\end{tabular}

The size of instrument used is the percentage of public school number in every province obtained from the Ministry of Education and Culture of Indonesia. With all the limitations, this study can only get the percentage data from inter-provinces, while ideally it is the percentage inter-regencies/cities for every year of junior high school national exit exam. As a result, variations of variable instruments are limited. The result of variable instrument method is depicted in table 7 (the complete first-stage result is given in the appendix), in which only variables of interest are presented. The results 
show that students of public Junior secondary school have a 0.572 higher of standard deviation in their National Exit Exam scores compared to that of private school students. The condition for percentage variable as instrument is fulfilled, i.e. the value of statistic $\mathrm{F}$ at the first stage is more than 10 and the presence of significant relation between publicjss variable and instrument variable percentage, although the estimation result of IV has a higher value than that of the OLS. If it is concluded from the OLS and FE methods that the OLS estimation results in an upward bias selection, the IV estimation turns out to yield a higher estimate.

Finally, the effect of average private school type choice attended by junior high school students on National Exit Exam Scores is estimated. Students' National Exit Exam Scores regression toward multi dummy is constructed. In this case, private school type is divided into secular private, Islamic private, and non-Islamic private, while public school serves as the basis. Since the percentage of the number of each private school is not found either from the IFLS or from the Ministry of Education and Culture data, the instrumental variable method is not applicable, thereby it is only possible to review using the OLS and FE.

Table 8. The Effect of School Type on National Exit Exam Scores

\begin{tabular}{|l|c|c|}
\hline & $\begin{array}{c}\text { OLS } \\
\text { jssnees }\end{array}$ & $\begin{array}{c}\text { FE } \\
\text { jssnees }\end{array}$ \\
\hline \multirow{3}{*}{ Privatejss } & $\mathbf{b} / \mathbf{s e}$ & $\mathbf{b} / \mathbf{s e}$ \\
& $-0.377^{* * *}$ & $-0.488^{* * *}$ \\
& $(0.056)$ & $(0.134)$ \\
Nomicjss & $-0.243^{* * *}$ & 0.077 \\
& $(0.052)$ & $(0.13)$ \\
& -0.135 & -0.339 \\
& $(0.133)$ & $0.334)$ \\
\hline R-squared & 0.105 & 0.191 \\
$N$ & 4550 & 1973 \\
\hline
\end{tabular}

Notes: *significance of $10 \%,{ }^{* *}$ significance of $5 \%$ and ***significance of $1 \%$. All control variables discussed are included in the equation.

Source: Author' Calculations.

The estimation result shown in table 8 only covers variables of interest. All the significant coefficients have negative characteristics, which demonstrate that both 
secular private and Islamic private schools have a smaller National Exit Exam Scores than public schools. Students of secular private junior high school have 0.377 and 0.488 lower standard deviation in the average JSS National Exit Exam Score compared to that of public school students using the methods of OLS and FE respectively. Students of Islamic private school have a 0.243 lower standard deviation in the average JSS national Exit Exam Score than that of public school students using the OLS method. Meanwhile, by employing the FE method, Islamic private schools have positive characteristics which signify higher National Exit Exam scores compared to public schools though the estimation is insignificant. As for non-Islamic private school students, though the result of coefficient estimation is insignificant, they also have positive characteristics, which means lower outcome than students of public schools.

\section{CONCLUSIONS}

The objective of this study is to see how the choice of Junior Secondary School type affects students' score achievement in the national exit exam. In practice, students attending public schools have higher scores than those attending the private ones. The three methods used in this study, i.e. OLS, FE, and IV show a similar result which means robust for these three estimation strategies.

A study by Newhouse and Beegle (2006) found 0.227, 0.244, and 0.308 higher of standard deviation in the JSS National Exit Exam Score for public school students using the method of OLS, FE, and IV respectively, although the IV estimate is insignificant. Compared to them, the empirical result in this study by using the data of IFLS 2, IFLS 3 and IFLS 4 found that public schools students have higher of standard deviation of 0.30 , 0.247 and 0.572 in the JSS National Exit Exam Score for the method of OLS, FE and IV respectively, in which all of the estimation values are significant.

Moreover, the academic performance for secular private schools is lower than that of both Islamic private schools and non-Islamic private schools. Even though the nonIslamic private schools are higher than the other two private schools, the estimate is not significant.

It is interesting to note that an increase in the consumption expenditure per capita decreases the probability of parents in putting their children to secular private and Islamic private schools. It indicates that the influence of perception that public 
schools are better than private schools is more significant than the preference of wealthy parents putting their children to private schools.

Primary School's national exit exam score positively and significantly affects Junior Secondary School's national exit exam score in all three analysis methods. Since a high score in National Exit Exam of Primary School is a prerequisite to enter public schools, it indicates that a better input for public schools is of certain benefit for the achievement in academic scores in the level of Junior Secondary School. Parents choosing private schools may be due to the limited quota of public schools with their limit of Primary School National Exit Exam Scores, the expectation of getting additional religious lesson, or the idea that private schools offer special non-academic qualities like discipline, comfort, and travelled distance.

\section{REFERENCES:}

Bedi, A. and Garg, A. (2000). The Effectiveness of Private Versus Public Schools: the Case of Indonesia. Journal of Development Economics 61(2):463-94.

Cox, D. and Jimenez, E., (1991). The Relative Effectiveness of Private and Public Schools: Evidence from Two Developing Countries. Journal of Development Economics 34, 99-121.

Duflo, E. (2001). Schooling and Labor Market Consequences of School Construction in Indonesia: Evidence from an Unusual Policy Experiment. American Economic Review, 91(4), 795-813

Evans, W.N. and Schwab, R.M., (1995). Finishing High School and Starting College: Do Catholic Schools Make a Difference? Quarterly Journal of Economics 105, 941-974

Figlio, D.N. and Stone, J.A.,(1997). School Choice and Student Performance, Are Private Schools Really Better? Discussion Paper No. 1141-97, Institute for Research on Poverty, University of Wisconsin-Madison.

Neal, D. (1997). The Effect of Catholic Secondary Schooling on Educational Attainment. Journal of Labor Economics 15, 98-123.

Newhouse, D. and Beegle, K., (2006). The Effect of School Type on Academic Achievement: Evidence from Indonesia. Journal of Human Resources, Vol 41. No.3, $529-557$

Sander, W. (1996). Catholic Grade Schools and Academic Achievement. Journal of Human Resources 31, 540-548. 


\section{Appendix}

First stage result for Variable Instrument method

First-stage regressions

First-stage regression of publicjss:

OLS estimation

Estimates efficient for homoskedasticity only

Statistics consistent for homoskedasticity only

$\begin{array}{llrrr}\text { Total (centered) SS } & =955.0997802 & \text { Centered R2 } & = & 0.1127 \\ \text { Total (uncentered) SS } & = & 3186 & \text { Uncentered R2 }= & 0.7340 \\ \text { Residual SS } & =847.4202844 & \text { Root MSE } & =\end{array}$

$\begin{array}{ll}\text { Number of obs } & \\ \mathrm{F}(24,4525) & =23.96 \\ \text { Prob }>\mathrm{F} & =0.0000 \\ \text { Centered R2 } & 0.1127 \\ \text { Uncentered R2 } & =0.7340 \\ \text { Root MSE } & =.4328\end{array}$

\begin{tabular}{|c|c|c|c|c|c|c|c|}
\hline Publicjss & | & Coef. & Std. Err. & $t$ & $P>|t|$ & [95persen & Conf. Interval] \\
\hline Inpce & | & .013753 & .0084334 & 1.63 & 0.103 & -.0027806 & .0302865 \\
\hline tile_floor & | & -.0316665 & .0186283 & $-1 \cdot 70$ & 0.089 & -.0681871 & .0048541 \\
\hline cement_floor & | & -.0197885 & .0183083 & -1.08 & 0.280 & -.0556817 & .0161047 \\
\hline lumber_floor & | & .0568846 & .0280062 & 2.03 & 0.042 & .0019787 & .1117905 \\
\hline bamboo_floor & | & -.2133123 & .1538204 & $-1 \cdot 39$ & 0.166 & -.5148754 & .0882507 \\
\hline dirt_floor & | & -.0936194 & .0327447 & -2.86 & 0.004 & -.157815 & -.0294239 \\
\hline psnees & | & .0244393 & .0039854 & 6.13 & 0.000 & .016626 & .0322526 \\
\hline fail_grade p & | & -.0380969 & .0185342 & -2.06 & 0.040 & -.0744329 & -.0017609 \\
\hline jssgradmothe & | & .0051733 & .0171696 & 0.30 & 0.763 & -.0284875 & .0388341 \\
\hline sssgradmothe & | & .0177792 & .0262937 & 0.68 & 0.499 & -.0337693 & .0693276 \\
\hline unigradmothe & | & .0643534 & .0416641 & 1.54 & 0.123 & -.0173287 & .1460354 \\
\hline jssgradfath & 1 & .0024613 & .0164768 & 0.15 & 0.881 & -.0298414 & .0347639 \\
\hline
\end{tabular}




\begin{tabular}{|c|c|c|c|c|c|c|c|}
\hline sssgradfath & । & .0595799 & .0229533 & 2.60 & 0.009 & .0145803 & .1045796 \\
\hline unigradfat & I & .0727333 & .0361498 & 2.01 & 0.044 & .001862 & .1436045 \\
\hline Islam & । & -.0010318 & .0204021 & -0.05 & 0.960 & -.0410299 & .0389663 \\
\hline sex & I & .0034202 & .0130353 & 0.26 & 0.793 & -.0221354 & .0289758 \\
\hline work_jss & । & -.0488309 & .0264331 & -1.85 & 0.065 & -.1006527 & .0029909 \\
\hline travltime_ $\sim p$ & I & .000824 & .0007934 & 1.04 & 0.299 & -.0007314 & .0023794 \\
\hline langindo & 1 & .0171643 & .0161358 & 1.06 & 0.288 & -.0144697 & .0487984 \\
\hline r_stown & I & -.0168883 & .0155729 & -1.08 & 0.278 & -.0474187 & .0136422 \\
\hline r_bcity & । & -.0691334 & .0207906 & -3.33 & 0.001 & -.1098932 & -.0283735 \\
\hline Jawabali & I & .1384065 & .0183201 & 7.55 & 0.000 & .1024902 & .1743229 \\
\hline schooltype d & । & -.1585227 & .0093841 & -16.89 & 0.000 & -.1769202 & -.1401252 \\
\hline percentage & 1 & .0049912 & .0005392 & 9.26 & 0.000 & .0039341 & .0060483 \\
\hline _cons & । & .3703101 & .1151898 & 3.21 & 0.001 & .1444817 & .5961384 \\
\hline
\end{tabular}

Included instruments: Inpce tile_floor cement_floor lumber_floor bamboo_floor dirt_floor psnees fail_grade_ps jssgradmother sssgradmother unigradmother jssgradfather sssgradfather unigradfather Islam sex work_jss traveltime_jss langindo r_stown r_bcity Jawabali schooltype_ps percentage

Partial R-squared of excluded instruments: 0.0186

Test of excluded instruments:

$$
\begin{aligned}
& \mathrm{F}(1,4525)=85.69 \\
& \text { Prob }>\mathrm{F}=0.0000
\end{aligned}
$$

Summary results for first-stage regressions

\begin{tabular}{l|cccccc} 
Variable | Shea Partial R2 | & Partial R2 & F $(1,4525)$ & P-value \\
publicjss | & 0.0186 & 0.0186 & $\mid$ & 85.69 & 0.0000
\end{tabular}




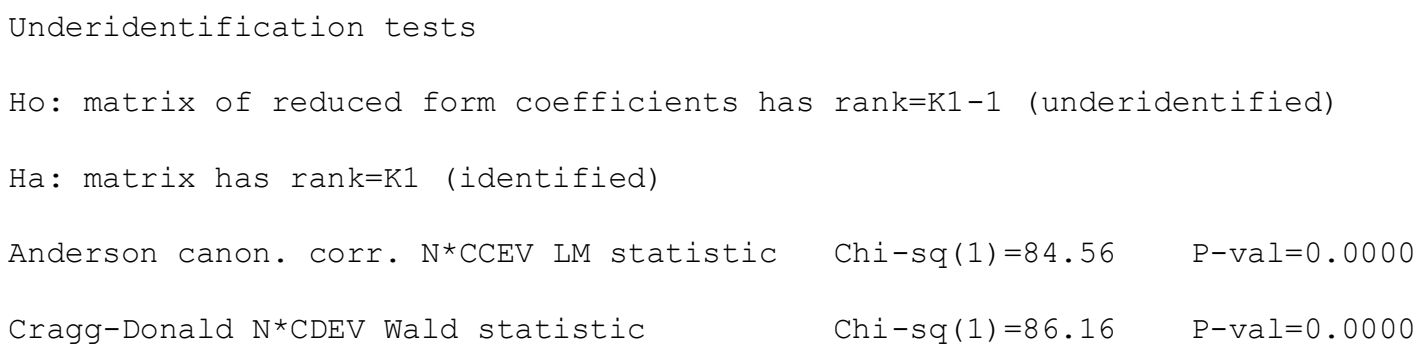

